\title{
Manifestasi Budaya Literasi dalam Kegiatan Perpustakaan Masyarakat Studi pada Perpustakaan Omah Sinau Kelurahan Tanjung Sari Kecamatan Jambi Timur
}

\author{
Wahyu Indri Astuti, Muhammad Rum, Syamsuddin \\ Fakultas Adab, UIN Sulthan Thaha Saifuddin Jambi \\ ${ }^{1}$ Jalan Jambi - Muaro Bulian Km.16, Muaro Jambi, 36363 \\ e-mail: wahyuindri833@gmail.com
}

\begin{abstract}
Intoduction. This study aims to determine the embodiment of literacy culture in the Community Library activities which were pioneered by the Omah Sinau Library in Tanjung Sari Village, Jambi Timur District. The importance of improving the literacy culture of the community is realized by the Omah Sinau library to answer the challenges of the times in the era of technological and information advancement. The existence of the Omah Sinau Library makes a positive contribution in providing sources of information and supporting skills activities for people of all ages and work backgrounds.

Research methods. This study uses a qualitative method with a descriptive approach. Qualitative research methods are used for in-depth understanding of human and social problems, not describing the surface of a reality

Data analysis. Data analysis using reduction, data presentation and conclusion drawing Results and Discussion. This research shows that the activities carried out by the Omah Sinau Library in Realizing a Literacy Culture for the Community are by providing literacy sources/reading materials; Making the library as a Media for Recreation/Entertainment; Making Libraries a Skills Education; Making the Library a Social Center for the Community.

Conclusions and suggestions. The library's contribution to improving literacy culture has a very positive impact on the surrounding community. The role of libraries that make libraries as social centers of society is a new finding in this research that has not existed in the same type of research before. It is hoped that the existence of community libraries, especially in Jambi City, can increase in number and the Omah Sinau library can be used as a reference library whose activities support the improvement of literacy culture.
\end{abstract}

Keywords: Literacy Culture, Community Library

\begin{abstract}
ABSTRAK
Pendahuluan. Penelitian ini bertujuan untuk mengetahui perwujudan budaya literasi dalam kegiatan Perpustakaan Masyarakat yang di pelopori oleh Perpustakaan Omah Sinau di kelurahan Tanjung Sari Kecamatan Jambi Timur. Pentingan meningkatkan budaya literasi masyarakat di sadari oleh perpustakaan Omah Sinau untuk menjawab tantangan zaman di era kemajuan teknologi dan informasi. Keberadaan Perpustakaan Omah Sinau memberikan kontribusi yang positif dalam menyediakan sumber informasi dan mendukung kegiatan keterampilan bagi masyarakat dari semua tingkatan usia dan latar belakang pekerjaan.
\end{abstract}


Metode penelitian. Penelitian ini menggunakan metode kualitatif dengan pendekatan deskriptif. Metode penelitian kualitatif digunakan untuk pemahaman yang mendalam tentang masalah-masalah manusia dan sosial, bukan mendeskripsikan bagian permukaan dari suatu realitas

Data analisis. Analisis data menggunakan reduksi, penyajian data dan penarikan kesimpulan

Hasil dan Pembahasan. Penelitian ini menunjukkan bahwa kegiatan yang dilakukan oleh Perustakaan Omah Sinau dalam Mewujudkan Budaya Literasi Masyarakat adalah dengan cara Menyediakan sumber-sumber literasi/bahan bacaan; Menjadikan perpustakaan sebagai Media Rekreasi/Hiburan; Menjadikan Perpustakaan sebagai Pendidikan Keterampilan; Menjadikan Perpustakaan sebagai Pusat Sosial Kemasyarakatan.

Kesimpulan dan Saran. Kontribusi perpustakaan dalam meningkatkan budaya literasi memberikan dampak yang sangat positif bagi masyarakat di sekitarnya. Peran perpustakaan yang menjadikan perpustakaan sebagai pusat sosial kemasyarakatan merupakan temuan baru dalam penelitian ini yang belum ada pada jenis penelitian yang sama sebelumnya. Diharapkan keberadaan perpustakaan masyarakat khususnya di Kota Jambi bisa bertambah jumlahnya dan perpustakaan Omah sinau bisa dijadikan perpustakaan rujukan yang kegiatan didalamnya mendukung peningkatan budaya literasi.

Kata Kunci: Budaya Literasi, Perpustakaan Masyarakat

\section{A. PENDAHULUAN}

Pada saat ini, banyak individu memahami bahwa budaya literasi itu penting. Tapi kenyataannya, Indonesia tergolong negara yang budaya literasinya rendah. Hal tersebut sesuai dengan pernyataan UNESCO menyatakan bahwa tingkat minat membaca di Indonesia sangat rendah dibandingkan anggota negara-negara ASEAN yang jumlahnya sebatas 0,001. Artinya hanya ada satu dari seribu orang Indonesia yang memiliki ketertarikan dalam membaca. Rata-rata masyarakat Indonesia hanya membaca nol sampai satu buku dalam satu tahun, sedangkan negara-negara anggota ASEAN membaca dua sampai tiga buku dalam setahun(Nugraha,dkk: 2019:145). Senada dengan Programme for International Student Assessment (PISA) 2015 menyebutkan pada awal Desember 2016 menunjukkan hasil bahwa budaya literasi Indonesia berada di urutan ke 64 dari 72 negara (Atmazaki,2017:4). Studi Most Littered Nation In the World yang dilakukan oleh Central Connecticut State University pada 
Maret 2016 lalu, juga menyebutkan bahwa Indonesia dinyatakan menduduki peringkat ke 60 dari 61 negara soal minat membaca. Indonesia persis berada di bawah Thailand (59) dan di atas Bostwana (61). Padahal, dari segi penilaian infrastruktur untuk mendukung membaca peringkat Indonesia berada di atas negara-negara Eropa (Harini, 2018:30).

Berdasarkan hasil penelitian yang dilakukan oleh Tine Silvana Rachmawati, dkk mengungkapkan bahwa budaya literasi informasi pada masyarakat yang ada di daerah pesisir pantai selatan Provinsi Jawa Barat pada umumnya masih rendah. Akses masyarakat terhadap bahan bacaan juga masih kurang serta dukungan pemerintah dalam upaya pembinaan budaya literasi masyarakat khususnya yang ada di daerah pesisir masih rendah. Hal ini terlihat dari jarangnya peraturan-peraturan pemerintah daerah serta program-program yang berkaitan dengan budaya literasi masyarakat (Rachmawati,dkk: 2018).

Keberadaan perpustakaan masyarakat memiliki peran yang sangat penting dalam meningkatkan budaya literasi tersebut. Hal ini terlihat dari kegiatan dan kontribusinya yang menyentuh semua kalangan dan dapat di akses dengan mudah oleh masyarakat di sekitarnya sehinggan layanan yang disediakan bisa di manfaat secara maksimal.

Perpustakaan Omah Sinau merupakan salah satu perpustakaan masyarakat yang berada di Kota Jambi. Perpustakaan ini banyak berperan dalam meningkatkan budaya literasi masyarakat disekitarnya. Hal ini terlihat dari beberapa penghargaan yang dimiliki oleh perpustakan tersebut. Dalam melaksanakan kegiatan perpustakaan, Perpustakaan Omah Sinau banyak mendapat tantangan di antaranya adalah sulitnya membangun kesadaran akan pentingnya membaca kepada masyarakat, banyak anak-anak menghabiskan waktunya hanya untuk bermain. Namun, sejak Perpustakaan Masyarakat Omah Sinau didirikan terjadi perubahan perilaku, budaya membaca disana semakin meningkat bahkan Ibu-Ibu Kelurahan Tanjung Sari ikut dalam kegiatan-kegiatan yang ada di Perpustakaan Masyarakat Omah Sinau tersebut. Maka dari itu penulis tertarik untuk meneliti manifestasi budaya 
literasi dalam kegiatan Perpustakaan Masyarakat studi pada Perpustakaan Omah Sinau Kelurahan Tanjung Sari Kecamatan Jambi Timur

\section{B. TINJAUAN PUSTAKA}

\section{Budaya Literasi}

Budaya Literasi adalah kebiasaan berfikir yang diikuti oleh sebuah proses membaca, menulis yang pada akhirnya apa yang akan dilakukan dalam sebuah proses kegiatan tersebut akan menciptakan sebuah karya (Iriantara,2009: 6). Literasi informasi memberikan kemampuan seseorang untuk menafsirkan informasi sebagai pengguna informasi dan menjadi penghasil informasi bagi dirinya sendiri.UNESCO dalam (Septiyanto, 2014: 1.17). manfaat dari literasi menurut Adam dalam (Septiyantono, 2014: 1.17), manfaat adalah:

1) Membantu mengambil keputusan. Literasi informasi sangat berperan dalam membantu menyelesaikan suatu persoalan. Untuk mengambil keputusan dalam menyelesaikan masalah, seseorang harus memiliki informasi tentang keputusan yang akan diambil.

2) Menjadi manusia pembelajar di era informasi. Kemampuan literasi informasi memiliki peran yang sangat penting dalam meningkatkan kemampuan seseorang menjadi manusia pembelajar. Semakin terampil seseorang mencari, menemukan, mengevaluasi, dan menggunakan informasi, semakin terbukalah kesempatan untuk selalu melakukan pembelajaran secara mandiri.

3) Menciptakan pengetahuan baru. Seseorang dikatakan telah berhasil dalam belajar apabila mampu menciptakan pengetahuan baru. Seseorang dengan kemampuan literasi informasi akan memiliki keterampilan memilih informasi mana yang benar dan mana yang salah sehingga tidak mudah percaya dengan informasi yang diperoleh.

Tumbuhnya budaya literasi pada diri seseorang pastinya tidak muncul begitu saja, tetapi menumbuhkan budaya literasi membutuhkan 
proses yang panjang (Rahmawati, dkk, nd: 2). Tumbuhnya budaya literasi dapat dipengaruhi oleh beberapa faktor diantaranya adalah, faktor lingkungan keluarga, faktor lingkungan masyarakat dan faktor lingkungan sekolah.

\section{Perpustakaan Masyarakat}

Perpustakaan masyarakat adalah suatu lembaga yang menyediakan bahan bacaan yang dibutuhkan oleh masyarakat, sebagai tempat penyelenggaraan pembinaan kemampuan membaca dan belajar, sekaligus sebagai tempat untuk mendapatkan informasi bagi masyarakat yang berada di sekitar lokasi taman bacaan masyarakat tersebut (Suwarno, 2010:31). Perpustakaan masyrakt merupakan tempat atau lembaga yang didirikan perorangan dan dikelola, baik itu masyarakat atau pemerintah yang melayani kebutuhan masyarakat akan informasi mengenai ilmu pengetahuan dan untuk menumbuhkan minat baca kepada masyarakat.

Perpustakaan masyarakat bertujuan untuk menyediakan akses sarana pembelajaran yang menyediakan dan memberi layanan bahan bacaan yang merata, meluas, dan terjangkau oleh masyarakat dengan mudah dan murah. Saepudin, dkk (2017:4) menguraikan bebebrapa tujuan dari perpustakaan masyarakat, yaknti sebagai berikut:

1) Meningkatkan kemampuan keberaksaraan dan keterampilan membaca.

2) Menumbuhkembangkan minat dan kegemaran membaca.

3) Membangun masyarakat membaca dan belajar.

4) Mendorong mewujudkan masyarakat pembelajar sepanjang hayat.

5) Mewujudkan kualitas dan kemandirian masyarakat yang berpengetahuan, berketerampilan, berbudaya maju, dan beradab.

Adapun manfaat dari perpustakaan masyarakat (Putri \& Setiadi, nd) adalah sebagai berikut:

1) Menumbuhkan minat, kecintaan dan kegemaran membaca.

2) Memperkaya pengalaman belajar bagi warga. 
3) Menumbuhkan kegiatan belajar mandiri.

4) Mempercepat proses penguasaan teknik.

5) Membantu pengembangan kecakapan membaca.

6) Menambah wawasan tentang perkembangan ilmu pengetahuan dan teknologi.

7) Melatih tanggungjawab melalui ketaatan terhadap aturan-aturan yang ditetapkan.

8) Membantu kelancaran penyelesaian tugas.

\section{METODE PENELITIAN}

Penelitian ini menggunakan penelitian kualitatif dengan pendekatan deskriptif. Penelitian kualitatif digunakan untuk pemahaman yang mendalam tentang masalah-masalah manusia dan sosial, bukan mendeskripsikan bagian permukaan dari suatu realitas sebagaimana dilakukan penelitian kuantitatif dengan positivismenya (Gunawan, 2015: 85). Lokasi penelitian beralamat di Perpustakaan Masyarakat Omah Sinau, Jl. Prabusiliwangi RT. 24 Kelurahan Tanjung Sari, Kecamatan Jambi Timur, Kota Jambi, 36147.

Data diperoleh melalui wawancara, observasi, dan dokumentasi. Pemilihan informan di dalam penelitian menggunakan teknik purposive sampling. Dimana terdapat 1 (satu) orang dijadikan sebagai key informan yang nantinya akan merekomendasikan informan lain untuk diwawancarai oleh peneliti. Adapun subjek dalam penelitian ini terdiri dari tujuh informan yaitu 1 (satu) pembina Perpustakaan Masyarakat Omah Sinau sebagai key informan, 2 (dua) pengelola Perpustakaan Omah Sinau, dan 4 (empat) masyarakat Kelurahan Tanjung Sari. Teknik analisis data dilakukan dengan cara reduksi data, penyajian data, dan penarikan kesimpulan. Uji keabsahan data dilakukan dengan teknik triangulasi. Triangulasi merupakan suatu cara mendapatkan data yang benar-benar absah dengan menggunakan pendekatan metode ganda yakni memeriksa keabsahan data dengan cara memanfaatkan 
sesuatu yang lain di luar data itu sendiri, untuk keperluan pengecekan data atau sebagai pembanding terhadap data itu (Gunawan, 2015: 219).

\section{HASIL DAN PEMBAHASAN}

1. Gambaran umum Perpustakaan Masyarakat Omah Sinau

Perpustakaan Masyarakat Omah Sinau Kelurahan Tanjung Sari Kecamatan Jambi Timur berdiri pada tanggal 23 Januari 2019 berdasarkan SK Kepala Kelurahan Tanjung Sari No. 8 Tahun 2019. Visi perpustakaan yakni "Perpustakaan Masyarakat Omah Sinau sebagai sumber informasi, rekreasi, dan tempat masyarakat belajar sepanjang hayat”. Saat ini perpustakaan Omah Sinau di pimpin oleh kepala perpustakaan yang bernama Caesar Janu Dilaga. Kepala perpustakaan dibantu oleh 2 (dua) bidang, yakni bidang teknis, bidang layanan pembaca. Masyarakat yang dilanai terdiri dari warga kelurahan Tanjung Sari, Mahasiswa/Pelajar/Masyarakat umum. Perpustakaan dibuka pada jam 09.00 - 16.00 WIB dari hari senin s/d minggu. Saat ini koleksi yang dimiliki oleh perpustakaan Omah Sinau berjumlah 1500 koleksi. Selain menyediakan sumber informasi berupa koleksi tercetak, perpustakaan juga mengadakan beberapa kegiatan diantaranya adalah: kegiatan keteramilan; seminar dan pelatiha; belajar bahasa Inggris; belajar bahasa Jepang; belajar tarian tradisonal, review buku, permainan mengasah otak, dan lain sebagainya.

2. Manifestasi budaya literasi dalam pengelolaan perpustakaan Omah Sinau

a. Menyediakan sumber-sumber literasi/bahan bacaan

Peran Perpustakaan Masyarakat Omah Sinau sebagai sumber informasi dalam mewujudkan budaya literasi adalah menyediakan sumber informasi seperti buku, novel, komik, dan majalah. Sumbersumber informasi yang ada di perpustakaan dapat dimanfaatkan oleh masyarakat untuk memenuhi kebutuhan informasinya. Koleksi yang terdapat di Perpustakaan Masyarakat Omah Sinau juga dapat dipinjam 
oleh pengguna perpustakaan. Hal ini sesuai dengan pernyataan Pembina perpustakaan omah sinau yakni informan "S":

"Di Perpustakaan Omah Sinau ini, kita menyediakan bukubuku dengan bermacam-macam jenis bukunya, untuk pertanian ada, kesehatan ada, dan untuk anak-anak juga ada. Di sini mayoritas pertanian, peternakan juga ada, jadi masyarakat bisa akses, mereka bisa memanfaatkan buku-buku sebagai sumber informasinya. Kita juga berlangganan bulanan internet, masyarakat bisa memanfaatkannya untuk belajar."

Selain itu, Perpustakaan Masyarakat Omah Sinau juga menyediakan wifi yang dapat digunakan untuk mencari informasi yang tidak terdapat di perpustakaan. Perpustakaan Masyarakat Omah Sinau juga mempunyai media sosial berupa Faceboook dan Instagram yang dipergunakan untuk berbagi informasi. Maka dari itu, perpustakaan harus memberikan layanan semaksimal mungkin agar mendapatkan respon positif dari pembacanya dan bisa menambah ilmu pengetahuan bagi pembacanya. Seperti yang di ungkapkan informan "WE" sebagai berikut:

"Pastinya setiap pengunjung yang datang ke sini, setelah mereka membaca buku tentu ilmu pengetahuan mereka bertambah. Misalnya seperti keterampilan, yang tadinya mereka tidak tahu cara membuatnya, dengan membaca mereka jadi tahu lalu mempraktekkanya. Lalu seperti resep masakan juga, yang tadinya mereka tidak bisa memasaknya jadi bisa. Kita juga pernah mengadakan bedah buku tentang reproduksi seperti remaja-remaja, yang tadinya tidak tahu tentang reproduksi jadi banyak belajar dan bertambah ilmu pengetahuannya dalam kegiatan ini."

Perpustakaan Masyarakat Omah Sinau berperan sebagai media atau jembatan yang berfungsi menghubungkan antara sumber informasi dan ilmu pengetahuan. Hal ini seperti dalam kegiatan diskusi, pelatihan-pelatihan dan bedah buku, serta ada beberapa pengguna yang aktif dan rajin membaca, dengan adanya kegiatan tersebut dapat menambah ilmu pengetahuan mereka. Kegiatan yang sudah dilakukan tersebut menunjukkan peran positif perpustakaan 
sebagai sumber informasi yang dapat diperoleh dari bahan pustaka. Semua bahan pustaka yang ada di perpustakaan adalah sesuatu yag sangat berharga, maka dari itu perlu dilestarikan dan dipelihara dengan baik agar tetap terjaga dan dapat dimanfaatkan oleh pengguna perpustakaan. Proses pelestarian terhadap bahan pustaka harus sangat diperhatikan agar semua bahan pustaka tersebut dapat dinikmati dalam jangka waktu yang lama.

Berikut peran Perpustakaan Masyarakat Omah Sinau sebagai tempat melestarikan koleksi bahan pustaka. Berdasarkan hasil wawancara antara peneliti dengan Ibu "S" sebagai pembina Perpustakaan Masyarakat Omah Sinau mengungkapkan:

"Kalau buku-buku di sini kan banyak buku bekas ya, jadi kadang ada yang bagus dan ada yang tidak. Kalau bukunya yang tidak bagus, misalnya seperti sampulnya tidak rapi ya tentu kita rapikan agar bisa tetap digunakan untuk dibaca."

Peneliti juga mewawancarai "WE" sebagai pengelola dalam bidang teknis Perpustakaan Masyarakat Omah Sinau dalam sesi wawancara yang peneliti lakukan bahwa beliau mengatakan:

"Kalau selagi masih layak dipakai dan dapat diperbaiki, biasanya kami hanya mengelemnya saja."

Perpustakaan Masyarakat Omah Sinau sudah berperan sebagai tempat melestarikan koleksi bahan pustaka agar koleksi tetap dalam keadaan baik, sehingga dapat dimanfaatkan oleh masyarakat pengguna. Apabila terdapat koleksi yang rusak dan masih dapat diperbaiki, mereka memperbaiki koleksi tersebut dengan cara di lem.

Koleksi bahan pustaka yang tetap terjaga dalam keadaan baik dapat meningkat budaya literasi bagi masyarakat. Budaya literasi, khususnya minat baca berperan penting bagi kehidupan, karena ilmu pengetahuan sejatinya dihasilkan melalui aktivitas membaca dan menulis. Apabila individu yang memiliki minat baca yang tinggi, secara otomatis membuat individu gemar membaca karena dapat melatih kemampuan berfikir, meningkatkan pemahaman, menambah 
wawasan dan pengetahuan, mengasah kemampuan menulis, mendukung keterampilan berbicara, dan menambah pembendaharaan kosa kata.

Berikut peran Perpustakaan Masyarakat Omah Sinau sebagai lembaga untuk mengembangkan minat baca, kegemaran membaca, kebiasaan membaca dan budaya baca. Berdasarkan hasil wawancara antara peneliti dengan informan "YT" selaku pengelola dalam bidang layanan pembaca Perpustakaan Masyarakat Omah Sinau beliau mengatakan:

"Remaja-remaja di sini sering kumpul untuk mengadakan pertemuan, nah mereka pasti membaca juga di sini. Selain itu, anak-anak yang tadinya sering main di rumah, semenjak ada perpustakaan ini, mereka sering datang ke sini dan membawa teman-temannya. Dengan melihat banyaknya buku di sini, timbul minat baca mereka, penasaran gitu kan, jadi mereka sering membaca juga."

Perpustakaan Masyarakat Omah sinau mempunyai peran sebagai lembaga untuk mengembangkan minat baca, kegemaran membaca, kebiasaan membaca dan budaya baca. Hal ini dapat dilihat dari pengunjung yang sudah cukup rajin membaca, bahkan mereka ada meminjam buku untuk dibawa pulang untuk dibaca.

Peran Perpustakaan Masyarakat Omah Sinau adalah menyediakan sumber-sumber informasi yang dapat menambah ilmu pengetahuan. Sumber-sumber informasi tersebut dipelihara dan dilestarikan oleh Perpustakaan Masyarakat Omah Sinau, terjaga dalam keadaan baik, sehingga terjadi perubahan pada budaya literasi masyarakat.

b. Menjadikan Perpustakaan sebagai Media Rekreasi/Hiburan

Perpustakaan berperan sebagai tempat rekreasi edukatif untuk masyarakat yang berguna dalam mewujudkan budaya literasi. Untuk itu dibutuhkan kreatifitas pengelola perpustakaan untuk mengeluarkan ide dan inovasi agar peran perpustakaan sebagai tempat rekreasi bisa 
terealisasikan. Gagasan dan ide-ide baru sangat dibutuhkan untuk membuat pandangan masyarakat menjadi tertarik datang ke perpustakaan. Maka dari itu, perpustakaan juga harus memberikan fasilitas yang baik agar orang yang berkunjung merasa nyaman, gembira, senang, terhibur dan pikiran bisa kembali fresh. Sehingga keberadaan perpustakaan tidak hanya sebagai tujuan keilmuan saja, tetapi juga sebagai tempat yang di tuju untuk berwisata, rekreasi, dan mencari hiburan yang asyik.

Berikut peran Perpustakaan Masyarakat Omah Sinau menjadikan perpustakaan sebagai media rekreasi/hiburan. Berdasarkan hasil wawancara antara peneliti dengan informan " $S$ " sebagai pembina Perpustakaan Masyarakat Omah Sinau mengungkapkan:

"Perpustakaan sebagai tempat rekreasi berbasis belajar yang pertama, selain aneka buku yang bisa diakses, kita juga menyediakan permainan non buku yang bisa digunakan untuk anak-anak bermain dan belajar. Kita juga ada peternakan kelinci yang anak-anak kadang datang sambil kasih makan, dan di sini kita juga ada bank sampah, sambil memilah sampah, anak-anak kita ajari pemilahan dan mereka juga bisa belajar warnanya. Selain itu, Ibu-ibu juga ada belajar keterampilan dan saya pikir mereka juga rileks, itu juga sebagai media rekreasi untuk masyarakat sekitar."

Senada yang dikatakan oleh "YT" sebagai pengelola dalam bidang layanan pembaca Perpustakaan Masyarakat Omah Sinau, beliau mengatakan:

"Menurut saya, perannya sebagai tempat rekreasi berbasis belajar, di sini kami menyediakan permainan seperti bowling, ular tangga dan permainan-permainan lainnya yang dapat mengasah otak. Kalau permainan bowling, misalnya kita lempar, lalu nanti ada yang jatuh, kita lihat pertanyaannya di situ, lalu sang pelempar tadi akan menjawab pertanyaannya."

Berdasarkan wawancara di atas yang disertakan observasi dan dokumentasi yang telah dilakukan, dapat diketahui bahwa peran Perpustakaan Masyarakat Omah Sinau menjadikan perpustakaan 
sebagai media rekreasi atau hiburan telah menyediakan berbagai permainan anak-anak, dan peternakan kelinci. Selain itu mereka juga membuat berbagai permainan yang dapat mengasah otak, seperti permainan bowling dan permainan ular tangga.

c. Menjadikan Perpustakaan sebagai Pendidikan Keterampilan

Peran perpustakaan dalam upaya mewujudkan budaya literasi dapat dilakukan dengan cara melakukan layanan perpustakaan seperti menyelenggarakan kelas keterampilan. Berikut peran Perpustakaan Masyarakat Omah Sinau sebagai tempat belajar keterampilan. Berdasarkan hasil wawancara antara peneliti dengan informan"S" sebagai pembina Perpustakaan Masyarakat Omah Sinau mengungkapkan:

"Untuk kelas keterampilan tangan, di sini membuat prakarya bunga yang terbuat dari plastik, kan kita memanfaatkan limbah juga. Berbagai prakarya yang kita buat itu dari limbah-limbah koran, kardus, tempat gelas, kain percah dan yang lain sebagainya. Sedangkan untuk Bapak-bapak ada membuat tong sampah, pot bunga dari tutup botol. Hasil prakarya ini nantiny dijual dan ini merupakan upaya untuk meningkatkan ekonomi. Dengan adanya kelas keterampilan ini, kadang Ibu-ibu juga menyempatkan waktunya untuk membaca tentang buku keterampilan untuk menambah wawasan keterampilan lainnya."

Senada yang dikatakan oleh "WE" sebagai pengelola dalam bidang teknis Perpustakaan Masyarakat Omah Sinau dalam sesi wawancara yang peneliti lakukan bahwa beliau mengatakan:

"Kalau keterampilan banyak ya, terutama Ibu-ibu. Mereka kan banyak tu baca-baca buku, nanti mereka lihat-lihat referensi di buku itu, nah nanti baru dipraktikan, misalnya buat bunga dari plastik, ada juga pot bunga dari tutup botol dan kertas koran jadi pot bunga."

Peneliti mewawancarai salah satu pengunjung

"S"Perpustakaan Masyarakat Omah Sinau, beliau mengatakan:

"Kelas keterampilan ini merupakan kegiatan yang positif. Biasanya sebelum mulai membuatnya, saya memanfaatkan akses internet untuk menonton di youtube tentang kerajinan 
tangan lalu baru dipraktekan. Hasil dari kerajinan ini kami jual lewat pameran dan alhamdulillah biasanya banyak yang membelinya. Hasil dari penjualan tersebut nanti kami bagi dan hasil dari kegiatan ini dapat menambah penghasilan Ibu-ibu di sini."

Berdasarkan wawancara di atas yang disertakan observasi dan dokumentasi yang telah dilakukan, maka dapat diketahui bahwa peran Perpustakaan Masyarakat Omah Sinau sebagai tempat belajar keterampilan berupa belajar kerajinan tangan yang kebanyakan dihasilkan oleh Ibu-ibu Kelurahan Tanjung Sari. Selain itu, Ibu-ibu di sana juga membaca buku sebelum mempraktekkannya dan ada sebagian juga yang belajar melalui media sosial berupa youtube. Hasil dari kerajinan tangan dijual melalui sebuah pameran dan hasil dari penjualan tersebut dibagi hasil, sehingga dapat menambah perekonomian masyarakat.

Upaya yang sudah dilakukan Perpustakaan Masyarakat Omah Sinau sebagai tempat belajar keterampilan dapat menjadikan perpustakaan tersebut menjadi salah satu lembaga pendidikan non formal. Perpustakaan merupakan lembaga pendidikan non formal yang berguna sebagai wadah untuk meningkatkan budaya literasi anggota masyarakat dan pengunjung perpustakaan. Berikut peran Perpustakaan Masyarakat Omah Sinau sebagai lembaga pendidikan non formal. Berdasarkan hasil wawancara antara peneliti dengan informan "S" sebagai pembina Perpustakaan Masyarakat Omah Sinau mengungkapkan:

"Pastinya setiap pengunjung yang datang ke perpustakaan Omah Sinau ini dapat menggunakan semua koleksi sesuai yang dibutuhkan oleh mereka yang nantinya dapat digunakan untuk belajar secara mandiri. Kadang ada anak-anak yang belajar di sini, mereka mengerjakan tugas sekolahnya di sini. Jadi, misalnya mereka membutuhkan referensi bisa langsung cari di perpustakaan Omah Sinau ini."

Peran Perpustakaan Masyarakat Omah Sinau menjadikan perpustakaan sebagai pendidikan keterampilan telah menyediakan 
tempat belajar berupa kelas keterampilan, kelas belajar bahasa Inggris dan belajar bahasa Jepang.

d. Menjadikan Perpustakaan sebagai Pusat Sosial Kemasyarakatan

Kemampuan bersosialisasi dengan masyarakat sangatlah penting dilakukan, karena dengan bersosialisasi dapat meningkatkan keaktifan dan kepedulian masyarakat dengan lingkungan sekitar.

Berikut peran Perpustakaan Masyarakat Omah Sinau sebagai sarana untuk menjalin dan mengembangkan komunikasi antara sesama pemakai. Berdasarkan hasil wawancara antara peneliti dengan Informan "S" sebagai pembina Perpustakaan Masyarakat Omah Sinau mengungkapkan:

"Di sini kan lumayan banyak pengunjungnya, jadi ketika mereka berkumpul, mereka saling tukar pikiran dan ada diskusi kecil-kecilan. Jadi, disitu terjalinlah komunikasi antar sesama pemakai."

Peneliti juga mewawancarai "WE" sebagai pengelola dalam bidang teknis Perpustakaan Masyarakat Omah Sinau dalam sesi wawancara yang peneliti lakukan bahwa beliau mengatakan:

"Dengan berkunjung ke Perpustakaan Omah Sinau ini, selain mereka membaca dan lain sebagainya, di sini mereka akan bertemu dengan pengguna perpustakaan lainnya dan mereka kadang berkenalan, sehingga di situlah terjalin komunikasi lalu mereka dapat saling tukar pikiran."

Senada yang dikatakan oleh "YT" sebagai pengelola dalam

bidang layanan pembaca Perpustakaan Masyarakat Omah Sinau, beliau mengatakan:

"Pengguna Perpustakaan Omah Sinau, selain membaca di perpustakaan, mereka juga sering saling mengobrol di sini, lalu bisa juga tukar pikiran antar sesama, dari saling tukar pikiran itu mereka jadi banyak terjalin komunikasinya."

Perpustakaan Masyarakat Omah Sinau sudah berperan baik sebagai sarana untuk menjalin dan mengembangkan komunikasi antara sesama pemakai. Hal ini dapat terlihat bahwa pemustaka tidak 
hanya membaca jika berkunjung ke perpustakaan, tetapi mereka juga saling bertukar pikiran satu sama lain antar sesama pengguna perpustakaan.

Peran Perpustakaan Masyarakat Omah Sinau sebagai agen perubahan, agen pembangunan dan agen kebudayaan. Berdasarkan hasil wawancara antara peneliti dengan "S" sebagai pembina Perpustakaan Masyarakat Omah Sinau mengungkapkan:

"Sebagai agen kebudayaan, Perpustakaan Omah Sinau cukup aktif melestarikan budaya seperti mengedukasi anak-anak untuk belajar tari tradisional dan belajar bermain alat musik rebana kepada anak-anak."

Peneliti juga mewawancarai "WE" sebagai pengelola dalam bidang teknis Perpustakaan Masyarakat Omah Sinau dalam sesi wawancara yang peneliti lakukan bahwa beliau mengatakan:

"Dengan adanya Perpustakaan Omah Sinau, masyarakat memiliki wadah untuk mempelajari tentang kebudayaan Indonesia seperti belajar tari tradisional, yang biasanya diikuti oleh anak-anak."

Senada yang dikatakan oleh "YT" sebagai pengelola dalam bidang layanan pembaca Perpustakaan Masyarakat Omah Sinau, beliau mengatakan:

"Perpustakaan sebagai agen perubahan, contohnya saja seperti keterampilan. Hasil dari keterampilan tersebut kan dijual, nah dari situ bisa merubah sedikit demi sedikit perekonomian masyarakat. Perpustakaan ini juga mengenalkan budaya, yaitu salah satunya dengan mengajarkan anak-anak belajar taritarian tradisional."

Berdasarkan wawancara yang disertakan observasi dan dokumentasi yang telah dilakukan, dapat disimpulkan bahwa peran perpustakaan sebagai agen perubahan, agen pembangunan dan agen kebudayaan adalah memperkenalkan budaya kepada anak-anak, seperti mengajarkan tarian tradisional dan belajar alat musik rebana.

Berikut peran Perpustakaan Masyarakat Omah Sinau sebagai barometer atas kemajuan masyarakat dilihat dari intensitas kunjungan dan pemakaian perpustakaan. Berdasarkan hasil wawancara antara 
peneliti dengan "S" sebagai pembina Perpustakaan Masyarakat Omah Sinau mengungkapkan:

"Kalau intensitas kunjungan di Perpustakaan Omah Sinau ini ada peningkatan. Kami bisa melihatnya dari buku tamu, tapi kadang-kadang ada tamu yang tidak mengisinya, tapi kalau berdasarkan hasil pengamatan saya selama ini sih banyak yang berkunjung ke sini, maksudnya semakin hari semakin meningkat."

Peneliti juga mewawancarai "WE" sebagai pengelola dalam bidang teknis Perpustakaan Masyarakat Omah Sinau dalam sesi wawancara yang peneliti lakukan bahwa beliau mengatakan:

"Kalau kita biasanya untuk melihat intensitas kunjungan, setiap ada kegiatan pasti ada absennya. Jadi dari situ kelihatan makin banyak atau malah tambah sedikit yang ikut. Kalau layanan membaca ada buku tamunya juga, sejauh ini yang saya lihat pengunjung makin hari makin bertambah."

Senada yang dikatakan oleh "YT" sebagai pengelola dalam bidang layanan pembaca Perpustakaan Masyarakat Omah Sinau, beliau mengatakan:

"Untuk melihat intensitas kunjungan pengguna, kita ada buku tamunya, kita bisa meliat di situ dan kalau ada kegiatankegiatan lainnya kita selalu menyediakan daftar hadirnya juga.

Jadi dari situ kita bisa tahu semakin banyak atau tidak yang ikut kegiatan."

Berdasarkan wawancara di atas yang disertakan observasi dan dokumentasi yang telah dilakukan, dapat diketahui bahwa Perpustakaan Masyarakat Omah Sinau sudah berperan sebagai barometer atas kemajuan masyarakat dilihat dari intensitas kunjungan dan pemakaian perpustakaan. Mereka mengetahuinya dengan cara menggunakan buku tamu dan absen kehadiran peserta setiap ada kegiatan diadakan.

Jadi, dapat disimpulkan bahwa berdasarkan hasil wawancara, observasi dan dokumentasi, peran Perpustakaan Masyarakat Omah Sinau menemukan temuan baru yaitu menjadikan perpustakaan 
sebagai pusat sosial kemasyarakatan melalui kegiatan diskusi, memperkenalkan budaya seperti mengajarkan tarian tradisional dan alat musik rebana. Kegiatan-kegiatan tersebut dapat dijadikan sebagai tolok ukur sosial masyarakat di Perpustakaan Masyarakat Omah Sinau.

\section{E. KESIMPULAN}

Perpustakaan Omah Sinau sangat memberikan kontribusi yang positif dalam mewujudkan budaya literasi masyarakat penggunanya. Peran yang telah diberikan oleh Perpustakaan Omah Sinau adalah:

1) Menyediakan sumber-sumber literasi/bahan bacaan

Dalam kegiatan menyediakan sumber literature/bahan bacaan peranan yang dilakukan Perpuatkaan Omah Sinau yakni sebagai tempat sumber informasi, berperan sebagai media atau jembatan yang berfungsi menghubungkan antara sumber informasi dan ilmu pengetahuan, sebagai tempat melestarikan koleksi bahan pustaka, sebagai lembaga untuk mengembangkan minat baca, kegemaran membaca, kebiasaan membaca dan budaya baca

2) Menjadikan perpustakaan sebagai Media Rekreasi/Hiburan menjadikan perpustakaan sebagai media rekreasi atau hiburan dilakukan perpustakaan dengan cara menyediakan berbagai permainan anak-anak, dan peternakan kelinci. Selain itu mereka juga membuat berbagai permainan yang dapat mengasah otak, seperti permainan bowling dan permainan ular tangga.

3) Menjadikan Perpustakaan sebagai Pendidikan Keterampilan

Perpustakaan Masyarakat Omah Sinau sebagai tempat belajar keterampilan berupa belajar kerajinan tangan yang kebanyakan dihasilkan oleh Ibu-ibu, ketika mempelajari kerajinan tangan, Ibu-ibu juga memanfaatkan bahan bacaan yang tersedia untuk menambah pengetahuan dan informasi. Perpustakaan Omah Sinau Kelurahan Tanjung Sari juga merupakan sebuah 
lembaga pendidikan non formal yang menyediakan tempat belajar berupa kelas keterampilan, kelas belajar bahasa Inggris dan belajar bahasa Jepang.

4) Menjadikan Perpustakaan sebagai Pusat Sosial Kemasyarakatan

Perpustakaan berperan sebagai sarana untuk menjalin dan mengembangkan komunikasi antara sesama pemakai. Selain itu, perpustakaan juga dijadikan sebagai barometer atas kemajuan masyarakat dilihat dari intensitas kunjungan dan pemakaian perpustakaan.

\section{DAFTAR PUSTAKA}

Ahmad Lukman Nugraha dkk. (2009) Signifikan Penerapan Literasi Ekonomi Islam di Perguruan Tinggi : Kajian Teoritis, Islamic Economics Journal Vol. 5, No. 1 Juni, hlm. 145. Diakses pada 13 Desember 2020 https://ejournal.unida.gontor.ac.id

Atmazaki. (2017). Panduan Gerakan Literasi Nasional. Jakarta : Kementerian Pendidikan dan Kebudayaan.

Encang Saepudin dkk. (2017). Peran Taman Bacaan Masyarakat (TBM) Bagi Anak-anak Usia Dini, Jurnal Kajian Informasi \& Perpustakaan Vol. 5, No. 1 Juni, hlm. 4. Diakses pada 20 Desember 2020 https://core.ac.uk/download/pdf

Ika Nur Harini. (2020). Tingkat Literasi Membaca Peserta Didik Kelas IV di SD Muhammdiyah Bantul Kota, Jurnal Al-Bidayah Vol. 10, No. 01 Juni 2018, hlm. $\quad 30 . \quad$ Diakses pada 13 Desember http://media.neliti.com/media/publications/284590-tingkat-literasimembaca-peserta-didik-k46a5e3dc.pdf\&ved

Imam Gunawan. (2015). Metode Penelitian Kualitatif: Teori \& Praktik. Jakarta : Bumi Aksara.

Tine Silvana Rachmawati, dkk, Studi Tentang Pemetaan Budaya Literasi Informasi pada Masyarakat Pesisir Selatan Jawa Barat. 
Tine Silvana Rachmawati, dkk. (2018). Studi Tentang Pemetaan Budaya Literasi Informasi pada Masyarakat Pesisir Selatan Jawa Barat, Record and Library Journal Vol. 4, No. 01 Januari-Juni. Diakses pada 11 Februari 2021 http://e-journal.unair.ac.id/RLJ/article

Tri Septiyantono. (2014). Literasi Informasi. Tangerang Selatan : Universitas Terbuka.

Wiji Suwarno. (2010) Pengetahuan Dasar Kepustakaan (Bogor : Ghalia Indonesia.

Yosal Iriantara. (2009). Literasi Media Bandung : Simbiosa Rekatama Media. 